\title{
Key Issues for Water Quality Monitoring in the Zambezi River Basin in Mozambique in the Context of Mining Development
}

\author{
Clemêncio M. Carlos Nhantumbo'1,2, Rolf Larsson'1, Dinis Juízo², Magnus Larson' ${ }^{1}$ \\ ${ }^{1}$ Water Resources Engineering, Lund University, Lund, Sweden \\ ${ }^{2}$ Faculty of Engineering, Eduardo Mondlane University, Maputo, Mozambique \\ Email: clemencio.nhantumbo@tvrl.Ith.se, rolf.larsson@tvrl.Ith.se, magnus.larson@tvrl.Ith.se, \\ n clemencio@hotmail.com, juizo@hotmail.com
}

Received 14 January 2015; accepted 26 March 2015; published 27 March 2015

Copyright @ 2015 by authors and Scientific Research Publishing Inc.

This work is licensed under the Creative Commons Attribution International License (CC BY). http://creativecommons.org/licenses/by/4.0/

(c) (i) Open Access

\begin{abstract}
Zambezi River Basin is located in Southern Africa. It is essential for the economy of its eight riparian countries. The delta and almost $11 \%$ of its total catchment area are located in Mozambique. The main stream of the river receives a run-off contribution of $1800 \mathrm{~m}^{3} / \mathrm{s}$ in Mozambique and reaches the ocean with a flow of about $4100 \mathrm{~m}^{3} / \mathrm{s}$. Coal mining is developing fast in the Zambezi River Basin in Mozambique due to favourable geological conditions. The coal mining and other activities have an impact on the surface and groundwater quality of the river basin. ARA-Zambeze is the river basin organization responsible for the water quality monitoring in Zambezi River Basin in Mozambique. In spite of limited resources ARA-Zambeze performs surveillance monitoring, while the institutions influencing the water quality of the river are doing operational monitoring. In this paper a monitoring system for the Zambezi River Basin in Mozambique is proposed. The system includes two alternative monitoring procedures. One procedure considers improvement of the current situation, which is characterized by multiple actors doing monitoring in isolation, by standardizing the analytical methods and improving data sharing through a web-based reporting system. The other proposed monitoring procedure considers a centralized approach, by having a consulting company doing the monitoring for the whole river basin in Mozambique. The second option has the advantages of improving consistency and comparability of the data, thereby allowing for more accurate trend analyses. It is concluded that the best way forward is to implement the first procedure and slowly move to the second.
\end{abstract}

\section{Keywords}

Zambezi River Basin, Coal Mining, Water Quality Monitoring, ARA-Zambeze 


\section{Introduction}

Mozambique is a developing country and its economy was based on agriculture until the 1990s. Recently, geological surveys showed that Mozambique was rich with mineral resources such as coal, gas, and heavy mineral sands. This led to the development of large scale mining since 2000s.

The coal mining is developing fast and is now alone representing $61 \%$ of mineral commodities, which makes Mozambique the second-largest exporter of coal in Africa after South Africa [1]. It is expected that the coal production will grow from about 0.036 million tons in 2010 up to 20 million tons in 2015 [1].

There are three major coal reserves in the Tete Province, Mozambique. This province is located within the largest river basin, the Zambezi River Basin, in Southern Africa, which sustains life for about 30 million people in the riparian countries. There are a lot of human activities being developed in the river basin such as water extraction for domestic and industrial uses, agriculture, livestock, fishing, and energy production [2]. Large scale coal mining and associated activities may have negative impacts on the water quality of the river, thus affecting the environment and human health.

Countries like China, Brazil, South Africa, and Australia with large scale coal mining are already experiencing the environmental effects of such activities [3]. Brazil, for example, is facing impacts on the water resources by contaminating drinking water and affecting agriculture in the north and south areas of Singão river basin, respectively [4]. In South Africa, acid mine drainage has become a serious issue and the authorities are engaged in planning sustainable mining to reduce future impacts [5].

The Regional Administration of Water in Zambezi River Basin in Mozambique (ARA-Zambeze) is the government river basin organization responsible for water quality management of Zambezi River Basin in Mozambique. ARA-Zambeze is not doing full monitoring of water quality of the river due to lack of resources. This makes it important to develop a low cost and sustainable water quality monitoring programme in the context of coal mining development.

This paper describes the actual situation of water quality monitoring in Zambezi River Basin and brings up the key issues for the establishment of a water quality monitoring programme in the context of coal mining development and other activities which may impact the water quality. The scope is to suggest a sustainable water quality monitoring system that takes into account the problem of lack of resources.

\section{Methods Used}

This paper is based on a literature review, compilation of general background data, and consultations with several institutions working with mining and water management in Mozambique.

A study visit to the area of interest was made in July 2012. The target institutions for the study visit were the coal mining companies, ARA-Zambeze, and the National Institute of Fish Investigation of Songo (IIP-Songo). Information about water quality in ARA-Zambeze was collected and IIP-Songo provided information about fish monitoring. The information about fish monitoring is mainly limited to the Cahora-Bassa dam. The information obtained from both institutions was limited due to lack of resources to do comprehensive monitoring and data management.

The other important institution that was visited during the study was the National Directorate of Mining, where information about coal production projections was obtained. In the National Directorate of Mining, the environmental assessment reports of two coal mining companies, highly useful for the study, were also found.

The content of this paper was further discussed in two seminars, one in Tete and the other one in Maputo on $25^{\text {th }}$ and $28^{\text {th }}$ of February 2014, respectively. Most important stakeholders involved in the water quality monitoring of Zambezi River Basin took part in the seminars and comments were collected to improve this paper.

\section{Description of the Study Area}

Zambezi River Basin (ZRB) is one of the most valuable and diversified natural resources in Africa. It is the largest river basin in Southern Africa with a surface area of $1.370 .000 \mathrm{~km}^{2}$ and average discharge at the outlet of $4100 \mathrm{~m}^{3} / \mathrm{s}$. Beyond sustaining life of 30 million people and keeping the natural environment rich and diversified, the river is essential for the economy of its riparian countries, which include Angola, Botswana, Malawi, Mozambique, Namibia, Tanzania, Zambia, and Zimbabwe (see Figure 1). The river is also essential for food security and hydroelectric energy production [2]. 


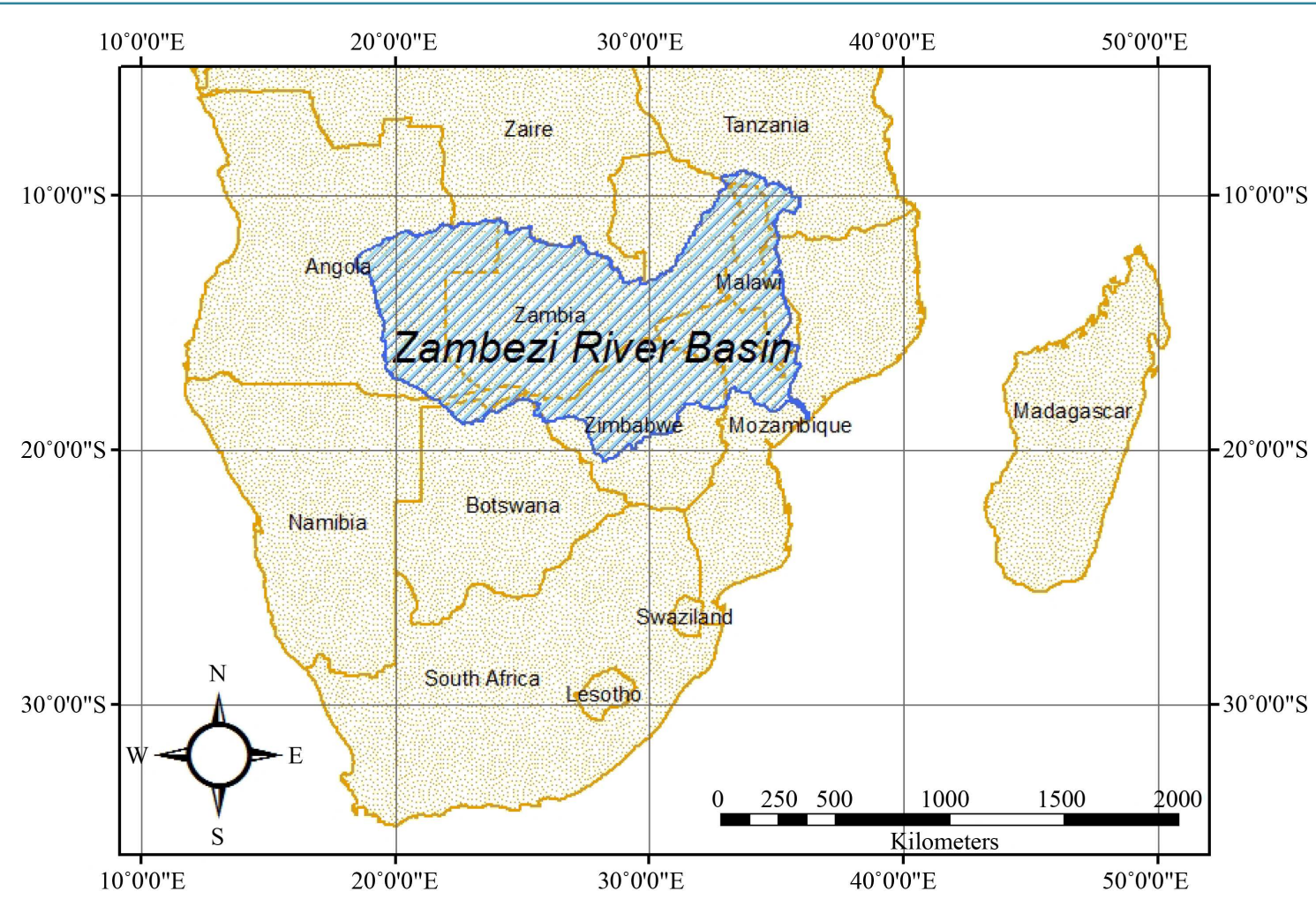

Figure 1. Zambezi River Basin.

Due to spatial variations in the rainfall distribution, the northern part of the basin contributes with larger volumes of run-off than the southern part, see Figure 2. The minimum average precipitation has been observed in the south to be about $500 \mathrm{~mm} / \mathrm{year}$ and the maximum in the northeast to be about $2400 \mathrm{~mm} /$ year. The overall average precipitation in ZRB is about $950 \mathrm{~mm} /$ year. Precipitation was estimated using ArcGIS and shape-files of precipitation from USGS [6].

The water of the Zambezi River Basin is used in several economic activities such as energy production, agriculture, fishing, tourism, and drinking water supply [2]. Several dams have been constructed along the river for water storage and/or for energy production. These dams influence the water flow and change the biodiversity in the riparian areas. There were 12 dams and almost 53 new projects of dams being analysed until 2008 [2], and the total installed capacity for energy production in Zambezi River is approximately $5000 \mathrm{MW}$. The largest hydroelectric power plant, Cahora-Bassa dam (2075 MW), is located in Tete Province in Mozambique [2].

With regard to agriculture, in 2008 Zimbabwe had the largest irrigated area among the riparian countries with 108,717 ha compared to Mozambique, which had only 8436 ha (World Bank, 2009). However, studies show that Mozambique has higher potential for irrigation compared to all other riparian countries with about 600,000 ha [2].

The domestic water supply in the ZRB is mainly from surface water (90\% of urban water and $15 \%$ of rural water supply), whereas the remaining water supply is from groundwater sources [7].

Approximately $11.5 \%$ of the total area of the Zambezi River Basin is located in Mozambican territory. A schematic map of the Zambezi River in Mozambique is shown in Figure 3. There are seven major tributaries and seven villages and/or cities along the river (ARA-Zambeze, n.d.). The Zambezi River itself crosses the Mozambican border with an average flow of about $2300 \mathrm{~m}^{3} / \mathrm{s}$ [2]. On its way through Mozambique it receives an additional $1800 \mathrm{~m}^{3} / \mathrm{s}$ of water, $70 \%$ of which is coming from the area which is expected to be affected by the coal mining [2]. This makes the average flow at the river mouth reach $4100 \mathrm{~m}^{3} / \mathrm{s}$. The length of the main river in Mozambique is about $800 \mathrm{~km}$.

The average precipitation in the Mozambican area of the Zambezi River Basin is approximately $1000 \mathrm{~mm} /$ year [6]. In general, the precipitation decreases from north to south [6]. The average actual evapotranspiration in the Zambezi River Basin in Mozambique is approximately $740 \mathrm{~mm} /$ year [8]. 


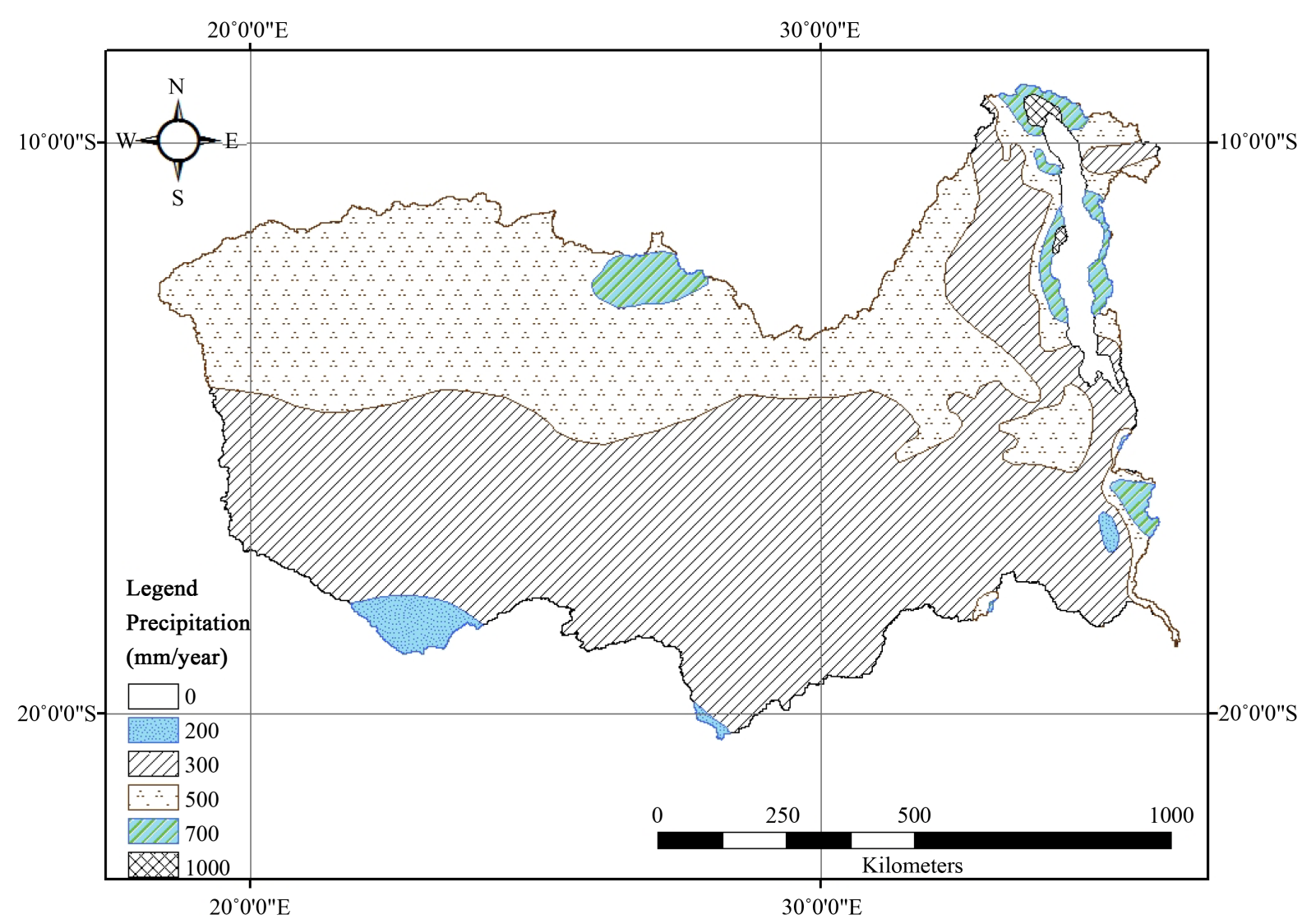

Figure 2. Precipitation in Zambezi River Basin, adapted from [6].

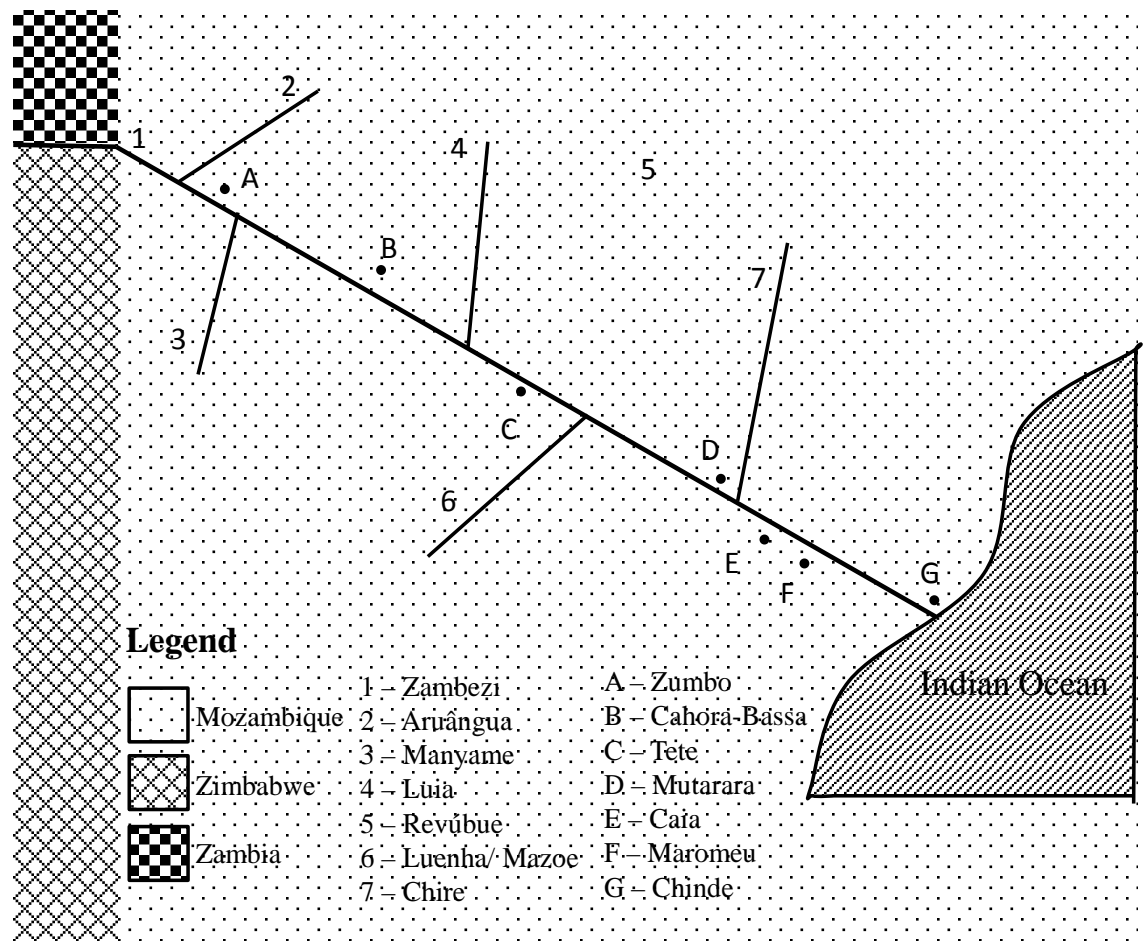

Figure 3. Hydrologic system of Zambezi River Basin in Mozambique (2 - 7 are tributaries and A-G are villages) [9]. The distance from Zambia (upstream country) to the Indian Ocean is approximately $800 \mathrm{~km}$. 
There is limited water quality data available for the Zambezi River Basin in Mozambique. ARA-Zambeze monitors $\mathrm{pH}$, temperature, electric conductivity, total dissolved solids, dissolved oxygen, salinity, turbidity, colour, smell, chlorates, total coliforms, and faecal coliforms [10]. The coal mining companies have some records of water quality analysis that includes more parameters, such as alkalinity, and these data are published in the environmental assessment reports [11]. These results show that the $\mathrm{pH}$ of the water in the Zambezi River Basin in Mozambique is almost neutral and most of the other monitored parameters are in the standard accordingly the Mozambican and South African legislation [10]. Reports from IIP-Songo suspect that the Cahora-Bassa dam is impacting negatively on the fishery in the ZRB and suggest studies about this issue [12].

\subsection{Water Management Framework in Zambezi River Basin}

The management of transboundary rivers is still a serious challenge in Southern Africa especially in ZRB. The difficulty of managing international river basins arises because countries have multiple and competing interests, e.g., inadequate river basin level institutional structure; constraints regarding institutional, legal, economic and human resources; poor data collection; and poor communication and inadequate training [13].

Knowing the importance of the river and different threats to a sustainable water management in the river, the riparian countries under the Southern African Development Community (SADC) agreed on the Zambezi River Action Plan Project in 1991 (Mott MacDonald, 2012). The project aimed to integrate development and management of the water resources in the SADC region to support sustainable economic and social development, regional integration, and eradication of poverty [14].

The action plan was implemented in two phases: Phase 1, from 1991 to 2000, was concerned with the development of a database to support the establishment of effective planning and management of the water resources of the region. Phase 2, from 2001 to 2008, had two main objectives, namely establishment of an institutional framework for management of shared water resources in ZRB and the formulation of an integrated water resources strategy for the river basin [14].

The negotiation aong the eight riparian countries led to an agreement signed by seven countries in 2005, thereby creating a river basin organization, the Zambezi Watershed Commission (ZAMCOM) [14].

The objective of ZAMCOM is "to promote the equitable and reasonable utilization of the water resources of the Zambezi watershed as well as efficient sustainable management thereof" [15]. Unfortunately, lack of resources and data availability limit the implementation of sustainable, integrated water resources management in ZRB.

The national water policy of Mozambique was approved by the government in resolution 7/95 of the ministers' council on the $8^{\text {th }}$ of August 1995. This policy prioritizes integrated management of water resources as a way to maximize the benefits of water use and to protect the environment.

Before the national water policy was published in 1995, the water law was approved and published in 1991. This law prioritizes river-basin based management of water and recognizes the regional administrations of water "Administração Regional de Águas" (ARA) as the institutions which have responsibility for water management. The ARA reports to the National Directorate of Water under the Ministry of Public Buildings and Habitation. The national water policy was further revised in 2007 and is now known as the water policy.

The regional administration of water responsible for the management of the Zambezi River Basin in Mozambique is ARA-Zambeze. The main office is located in Tete city, the capital of the Tete Province, and is responsible for the area shown in Figure 4.

ARA-Zambeze is responsible for:

- ensuring the rational usage of water resources;

- safeguarding surface water sources by controlling the flow to the ocean through the building of dams to store water;

- reducing the wastage of water through cooperation with other institutions that have more direct responsibilities;

- raising awareness in the population about water as an exhaustible resource, which will become a serious issue in the 21st century; and

- collecting fees for the usage of raw water that are used to maintain the hydrometric activity and to promote other activities to protect the water resources. 


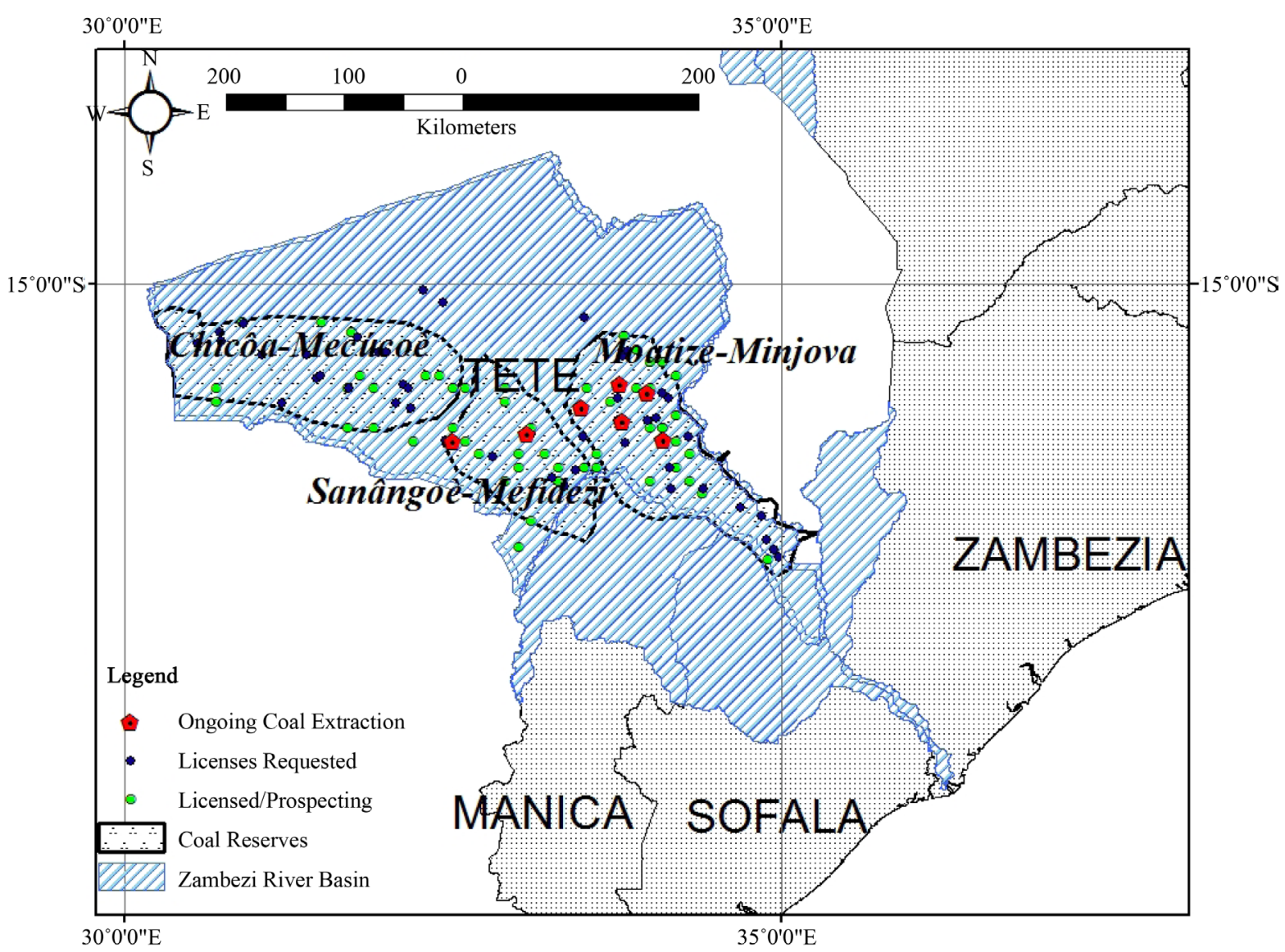

Figure 4. Coal mining in the Zambezi River Basin (data collected in MIREM).

In the future, the fees collected will include the recovery of investments in hydraulic infrastructures and the protection of the surface and groundwater resources against pollution and inadequate uses, which may result in high costs when making the water potable again [9]. However, the lack of resources limits the water quality monitoring performed by ARA-Zambeze.

The National Institute for Fishing Investigation of Songo (IIP-Songo) also plays an important role in water quality monitoring in ZRB in Mozambique by monitoring the population of fish in the river. However, the actual records of fish monitoring are more related to Cahora-Bassa dam and do not include the area affected by coal mining. There are other institutions that play important roles in the water quality monitoring such as the water supply companies and other companies that affect or can be affected by changes in the water quality of the river.

\subsection{Coal Mining in Tete}

The coal mining in Mozambique started during the colonial period in 1920 by Portuguese companies [16]. The activity of Moatize Company started in 1948 and in 1978 the government coal company CARBOMOC E. E. was established. The peak production of coal in that period was in 1981 with 575.000 tons. In 1983, the activities of CARBOMOC were stopped due to political problems [16].

In 2004 the Mozambican government launched an international contest for the development of the Moatize Coal Reserve that was won by Companhia do Vale do Rio Doce. In 2011 two projects of extraction of coal were started by two companies, the Moatize project by Vale MoçambiqueLda and the Benga Project by Rivesdale Moçambique, Lda. The Benga project is actually owned by Rio Tinto [16].

There are at present (2014) more than 60 licenses and 40 requests for licenses for coal mining in Mozambique that are owned by around 30 companies. There were three companies extracting coal at the end of 2011, all of which were located in Moatize: Vale Moçambique, Rio tinto, and Minas de Moatize [17]. In 2012 four more companies started with coal extraction: Jindal in Changara district, ENRC in Cahora-Bassa district, Ncondedzi 
Coal Company, and Minas Revúbue in Moatize [1].

Figure 4 shows the distribution of coal mining licences, requests for licenses, and mines in operation in the Tete Province. The seven mines in operation until now are run by international companies, and they are all located downstream of the Cahora-Bassa dam. The operational monitoring of water quality in the river, considering the development of coal mining, should therefore focus on the area downstream of Cahora-Bassa dam.

Figure 4 also shows that the mining is concentrated in three main coal deposits: Chicôa-Mecúcoè, Sanângoè-Mefídezi, and Moatize-Minjova [18]. These three coal deposits are all located near the main stream of the Zambezi River or its tributaries. If the coal is exploited in all licenced, areas the water quality of the river and its tributaries will be affected.

The Ministry of Mineral Resources (MIREM) has produced projections of coal production in Mozambique that show a growing coal production from 2.9 millions of tons in 2011 to 39.0 millions of tons in 2019. After this peak the production will reduce to 6.7 millions of tons until 2028, see Figure 5 . The projection of coal production was made considering the six main coal mining companies since the production of the other companies is relatively low. The coal production is expected to reduce dramatically in 2020 because one of the major coal mining companies is scheduled to close its operations at that time.

\section{Environmental Impacts of Coal Mining}

In general the wastewater from coal mining can be classified as mine water, process water, domestic wastewater, and surface run-off [19]. The biological pollutants in the coal mining can be found in the wastewater from domestic and sanitation facilities within the amenity buildings [19]. The mine and process water usually exhibit significant changes in physical and chemical parameters [19]. The run-off can be a potential problem if it comes into contact with tailings of mining and/or mine or process water.

The most common and serious problem of mining is the generation of acid mine drainage which contaminates both surface and groundwater sources [20]. Countries like South Africa, Australia, USA, and Brazil, which have extensive coal mining, are already experiencing such impacts.

The most likely sources of acid mine drainage are the mine water and the run-off in the mining area and/or areas where the tailings from the mining process are stored. Sometimes the process water can also have low $\mathrm{pH}$ values depending on the composition of the minerals and the contact time with the minerals during the process. The proposed classification of wastewater in a mining operation is shown in Figure 6. The mine water, process water, and run-off from the mine area should undergo special treatment. The domestic wastewater (WW) and run-off from the amenity area should be sent to the sewage system or treated in a domestic wastewater treatment plant (WWTP).

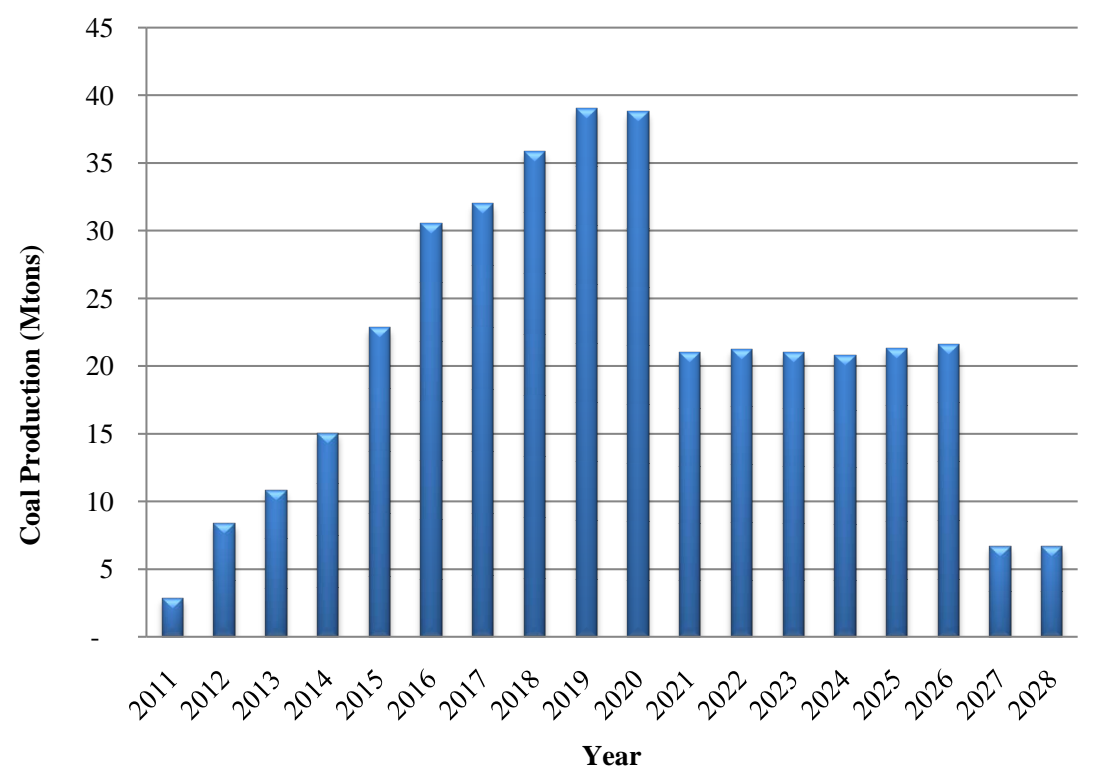

Figure 5. Projection of coal production in mozambique (data collected in MIREM). 


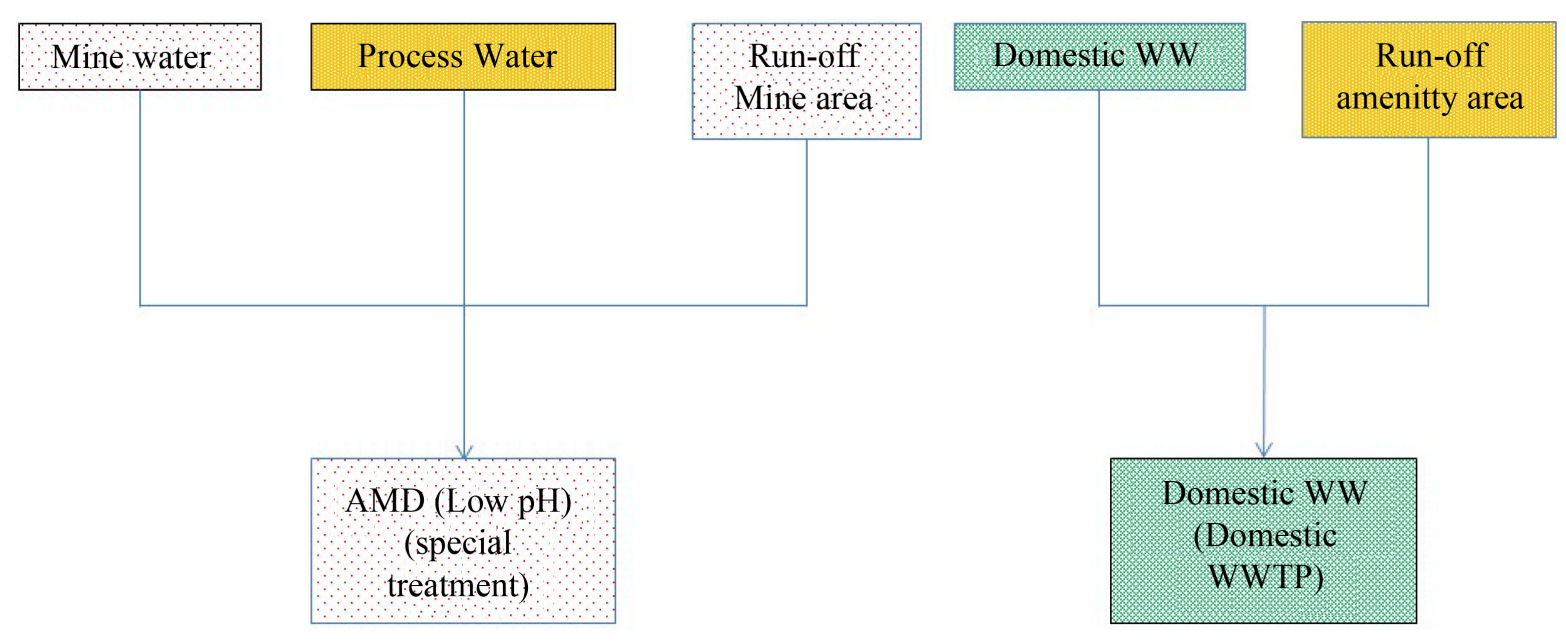

Most likely source of AMD

Less likely source of AMD

Not source of AMD

Figure 6. Wastewater generation in coal mines.

\section{Acid Mine Drainage}

Acid mine drainage (AMD) is formed when air and water come into contact with certain minerals associated with mining such as pyrite or other coal associated rocks containing sulphide. Sulphide reacts with oxygen from air and water to form acid and yields dissolved metals such as aluminium, iron, and manganese [21]. AMD is characterized by high concentration of salts, heavy metals, and radionuclides [22]. Typical pH value of AMD is 2 - 3 standards units [19].

The changing of $\mathrm{pH}$ and the leaching of heavy metals due to AMD influences directly the life in natural waters. The receiving waters affected by AMD can have levels of $\mathrm{pH}$ as low as 2 to 4.5 [23].

The environment and species (including humans) consuming or living in water affected by AMD may be impacted differently, depending on sensitivity.

Fish populations can be used as indicators of the condition of the water since they are sensitive to AMD. Some studies report no effect and successful reproduction of fish at $\mathrm{pH}$ around 6.5 and most species are not affected when $\mathrm{pH}$ is between 5.5 and 10.5. However, when the $\mathrm{pH}$ drops from 5.5 to 4.5 fish can be severely impacted [23]. An example of results obtained from a study about the tolerance of fish to pH drop is given in Table 1 .

Fish in water affected by AMD may die from direct exposure to heavy metals and hydrogen ions $\left(\mathrm{H}^{+}\right)$through their gills, impairing respiration resulting in chronic and acute toxicity. Fish are also exposed indirectly to the heavy metals by ingestion of contaminated sediments and food [23].

Another negative effect on rivers caused by AMD is the precipitation of common weathering products of sulphide oxidation, such as iron hydroxide, which coats the stream bed with an orange-red precipitate [20]. The precipitation of iron hydroxide and oxyhydroxides may coat the streambed sediments destroying the habitat and diminishing the amount of clean gravel for spawning [23].

Another study revealed abundance of insects and algae in water with $\mathrm{pH}$ above 4.5 compared to water with $\mathrm{pH}$ between 2.8 and 3.8 [23].

\section{Water Quality Monitoring Systems}

There are several water quality monitoring systems available and they are being constantly improved. A good 
Table 1. Tolerance of fish to pH drop [23].

\begin{tabular}{cc}
\hline $\mathrm{pH}$ & Number of Species \\
\hline $\mathrm{pH}>6.4$ & 68 species living in water \\
$5.6<\mathrm{pH}<6.4$ & 38 species living in water \\
$\mathrm{pH}<5.5$ & 10 species living in water \\
\hline
\end{tabular}

starting point for developing a new system is the following basic analysis: "The process of water-quality monitoring and assessment is a sequence of related activities, starting with the definition of the objectives and information needs and ending with the dissemination of the information product for use by communities, scientists and decision-makers to effectively allow the protection and sustainable management of national and transboundary water resources" [24]. The intermediate steps from objectives to the dissemination of the results may vary for different reasons such as the country development stage, objective of the monitoring, and system developer.

It is not possible to talk about water quality monitoring without the subsequent stage which is evaluation. Both the monitoring and evaluation are important tools for water management. Monitoring can be viewed as periodical measurements towards a short, medium, or long-term result [25] that are carried out to fulfill defined objectives. When a certain monitoring objective has been defined, a set of indicators are selected in order to answer the question raised by the objective [25].

The result of the monitoring only gives information directly related to the measured indicators or parameters. Evaluation is when the results obtained from the monitoring are compared with the results in the past or with certain standards [25]. The information generated might be that the quality of water is changing over time or that the content of a certain pollutant is higher or lower than the standard. The evaluation results directly influence the management of water and can be used by the decision-makers to take actions.

Three water quality monitoring systems are first analyzed in this paper: 1) Framework for Water Quality Monitoring; 2) Result-Based Monitoring and Evaluation; and 3) Monitoring System adopted by the European Union (EU) under EU Water Framework Directive. These systems are then combined to propose a sustainable water quality monitoring system for the Zambezi River Basin in Mozambique.

\subsection{Framework for Water Quality Monitoring}

The Framework for Water Quality Monitoring (FWQM) was developed and implemented in the USA. This system is proposed to enhance the production of consistent and comparable water quality information to support a fair and equitable water resources management [26]. The FWQM suggests that to produce more consistent and comparable information, interaction among water quality monitoring professionals is required [26]. The graphical representation of the FWQM proposed by the National Water Quality Monitoring Council (NWQMC) is shown in Figure 7.

Consistent and comparable water quality information is important in order to: 1) analyze the characteristics and trends of water quality; 2) identify emerging water quality issues; and 3) check the compliance with regulations [27]. Water quality monitoring is considered as a critical activity to support water quality management. Unfortunately, in most cases, the data and information produced from monitoring is not well organized and does not give maximum value for the money [27].

The FWQM considers six major interconnected elements as shown in Figure 7 [26]. The elements are: 1) develop monitoring objectives; 2) design monitoring program; 3) collect field and laboratory data; 4) compile and manage data; 5) assess and interpret data; and 6) convey results and findings. There are some issues, which have to be considered, that are not clearly specified in the six elements of the FWQM [27]. These issues can be classified in four categories: identify data users; engage monitoring partners; evaluate the monitoring program; and use information technology to connect the framework elements [27].

In the outer ring of FWQM, it is shown that to communicate, collaborate, and coordinate is important to meet the general objective of the monitoring, which can be to understand, protect, or restore a certain water body as shown in the middle of Figure 7 [26].

The objectives of the water quality monitoring are usually defined to answer the following questions: 1) Is the water acceptable to drink or for swimming and other aquatic uses or habits?; 2) Is water quality getting better or worse?; 3) Is the water quality changing due to certain water use or management?; 4) Are the water quality re- 


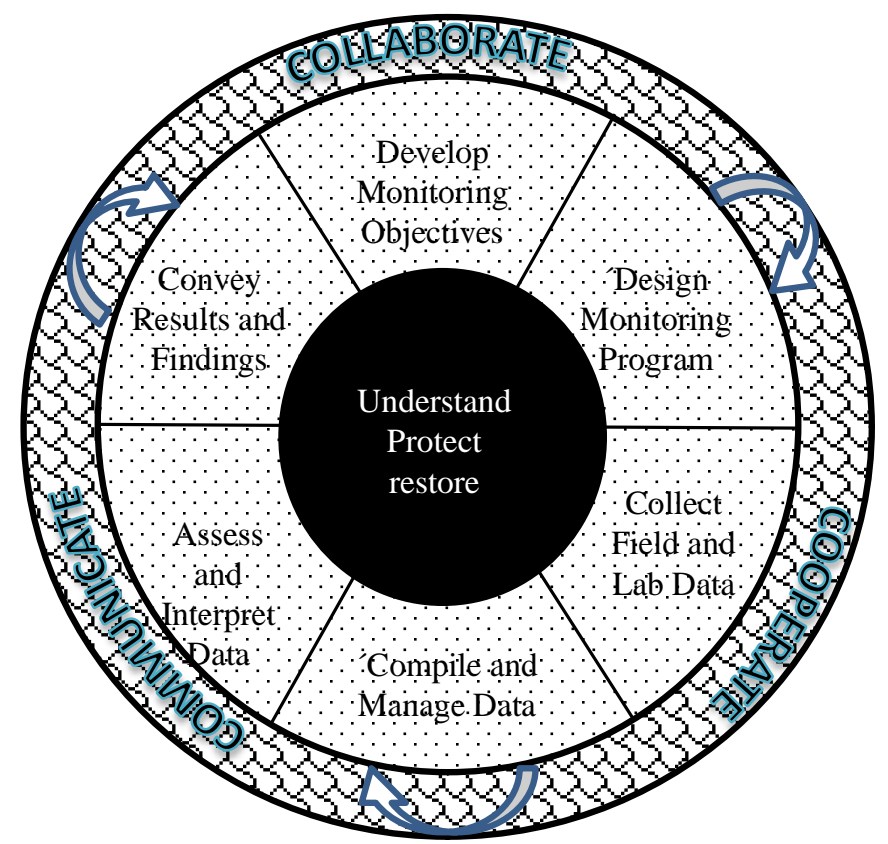

Figure 7. Framework for Water Quality Monitoring (FWQM) adapted from NWQMC (AWRA, 2004).

quirements being met?; and 5) How does the water quality of a certain water body compare with other water bodies? [28].

There are a number of issues that have to be considered when defining the monitoring objectives. The first element of FWQM describes how to select objectives that can be met with available resources and time. In monitoring, the financial resources, human resources, and available time are constraints that limit the objectives proposed [28]. The mismatch between the objectives proposed and the available resources and time can lead to project failure [28]. In addition to resources and time the variability of water characteristics, regulatory requirements, and shared monitoring efforts have to be considered when defining the monitoring objectives [28].

After defining the monitoring objectives the second element of the FWQM is to design the monitoring program. In this step it is important to consider the environment to be monitored, the parameters which will be measured, the methods to be used to collect data, the place to take the measurements or samples, and when to do the measurements and at which frequency [29]. It is also necessary to have an implementation plan, which should include quality assurance by training the personnel involved in the monitoring [29].

Collecting field and laboratory data is the third element of the FWQM. In this step it is important to ensure comparability of data [30], which allows the sharing of results between the different stakeholders involved in the monitoring process. This reduces the costs of the analyses and allows for consistent trend analyses.

The fourth element of the FWQM is to compile and manage data. It is difficult to ensure that data collected from different institutions are being stored correctly and that they were collected in a way that assures comparability. One important requirement in data management is that all data have to be well described (metadata). The recommended elements of metadata are: contact, result, reason for sampling, date and time, location, sample collection, and sample analysis [31].

The fifth element of the FWQM is to assess and interpret data [26], which is done by applying standard statistical methods [32].

The last element of the FWQM is to convey the results and findings, which is usually done through written reports. There are a number of issues to be considered when conveying results and findings such as the objective, the target audience, the message to be conveyed, and the ways used to convey the results [33].

\subsection{Result-Based Monitoring and Evaluation System}

The World Bank adopted ten steps for a result-based monitoring and evaluation system (RMES) for integrated 
water resources management [34]. The RMES came as a development of the traditional implementation-focused monitoring and evaluation, which was designed to address the "did they do it?" questions [25]. The weakness of implementation-focused monitoring and evaluation is that it does not provide the policymakers, managers, and stakeholders with an understanding of the success or failure of the monitoring project, program, or policy [25].

The RMES was designed to answer "so what?" questions, which it does by providing feedback on the actual outcomes and goals of government actions [25]. This monitoring system also checks to if the water quality is being protected by the coordinated actions implemented. There are ten steps suggested in order to implement the RMES, see Figure 8.

In the ten steps to build a RMES it is not explicitly indicated in which step the monitoring objectives are defined. However, it includes two very important steps namely 1) selecting the key indicators that determine the willingness of the different stakeholders to cooperate in the monitoring and 2) the outcomes to be monitored that are prerequisites to properly define the monitoring objectives. The last one of the ten steps includes an important element, not commonly discussed in the other monitoring systems, which is sustaining the system within the government. This step aims to ensure that the government goals are satisfied in order to guarantee the support for the monitoring program [25].

These steps for monitoring and evaluation were proposed to be implemented in the IWRM plan of Namibia published by the Ministry of Agriculture, Water and Forest [34]. The same report discusses a funding allocation procedure for the implementation of the IWRM that involves all the water users. This brings up the fourth principle of the Dublin Statements, which considers water as an economic goods and that the users should pay for the use of water to guarantee the availability of resources for its management and conservation. This system was also implemented in some developed countries such as Australia, Canada, the Netherlands, and United States [25].

\subsection{Water Monitoring System Adopted under EU Water Framework Directive}

Water quality monitoring under the EU Water Framework Directive (WFD) is part of the River Basin Manage-

\section{Ten Steps to Building a Performance Based M\&E System}

1 Conducting a Readiness Assessment - To determine the capacity and willingness of the governments and partners to implement the M\&E System. Identifying barriers, who will own, protectors and resisters to the implementation of M\&E System

2 Agreeing on Outcomes to Monitor and Evaluate - The outcomes should derive from the strategic goals of the country . They should be focused and drive the capability to allocate resources and activities of the government and its partners.

3 Developing Key Indicators to Monitor Outcomes - It is the mean of assessing if the outcomes are being achieved. Developing appropriate key indicators is crucial for M\&E process, it influences data collection, analysis and reporting.

4 Gathering Baseline data on Indicators - means essentially to take the first measurement's of the indicators or it can be viewed as the measurement of the initial conditions of the indicators toward the outcomes.

5 Planning for Improvements /Setting Realistic Targets - It is important to recognize that most of the outcomes are longterm, complex, and not easily achieved. Thus there is need to specify mid-term targets that specify the progress toward the outcomes

6 Monitoring for Results - It is administrative and institutional task of establishing data collection, analysis, and reporting guidelines.

7 Evaluative Information to Support Decision - making - Focus on the contributions that evaluations studies and analysis can make throughout the process of evaluating the results and movement toward the outcomes.

8 Analyzing and Reporting the Findings - It determines what findings are reported to whom, in what format and which intervals. It is a crucial step to produce information for M\&E System.

9 Using Findings - The process should not generate information only but it is important that the information reach the appropriate users in the system in reasonable time in order to be used to take decisions .

10 Sustaining the M\&E System Within the Government - There are six criteria which have to be considered when constructing a sustainable system: demand, structure, trustworthy and credibility of information, accountability, incentives and capacity.

Figure 8. Ten steps for building a result-based monitoring and evaluation system (RMES) adapted from: [25] [34]. 
ment Planning Cycle shown in Figure 9. There are two levels in this Cycle, the outer level that includes three steps (Develop and Publish the River Basin Plans; Implement Measures in Management plans; and Review Effectiveness of Management Plans), and the inner level that includes four steps (Setting/Reviewing of Quality Standards; Characterization; Monitoring; and Classification) [35].

The WFD requires the establishment of three types of monitoring programs: the surveillance, operational, and investigative Monitoring [36]. Surveillance monitoring gives an assessment of the overall surface water status within each catchment. Operational monitoring is required where pollution and other types of impact on the ecological status are apparent. Investigative monitoring is required where the surveillance monitoring shows that the objectives are not being met and where the operational monitoring is not yet established [36].

\section{Water Quality Monitoring System Proposed for Zambezi River Basin in Mozambique}

Three types of monitoring are done in the Zambezi River Basin: Surveillance, Operational, and Investigative Monitoring. The Surveillance Monitoring is done by ARA-Zambeze, where the monitoring includes only the basic parameters: temperature, $\mathrm{pH}$, electric conductivity, total dissolved solids, dissolved oxygen, orto redox phosphate, salinity, turbidity, color, smell, chlorates, total coliforms, and fecal coliforms [10]. The operational monitoring is done by the companies using and/or affecting the water of the river. Finally, the investigative monitoring is performed by the Institute of Fish Investigation of Songo and other research institutions. In this section a proposal, based on available legislation and other instruments, is presented for improving the three types of monitoring. The proposal has been developed along the principles provided by the three existing water quality monitoring systems described in the previous section.

The water law (law 16/91), approved by the Mozambican Parliament in 1991, in its chapter IV, prioritizes the protection of water quality. This shows that at least according to the legislation the water quality monitoring has the support of the government. This law also proclaims, in its article 55, the responsibility of the polluter, i.e., those water users who affect the water quality and change the water quality parameters beyond the standards, have the responsibility to cover all costs of reclamation and respond to applicable sanctions. This means that if the water users cooperate in the water quality monitoring coordinated by a government institution they will not face problems in the future, for example being forced to pay for reclamation of water resources damage, which can be very costly. A schematic representation of the water quality monitoring system proposed for the Zambezi River basin in Mozambique is shown in Figure 10.

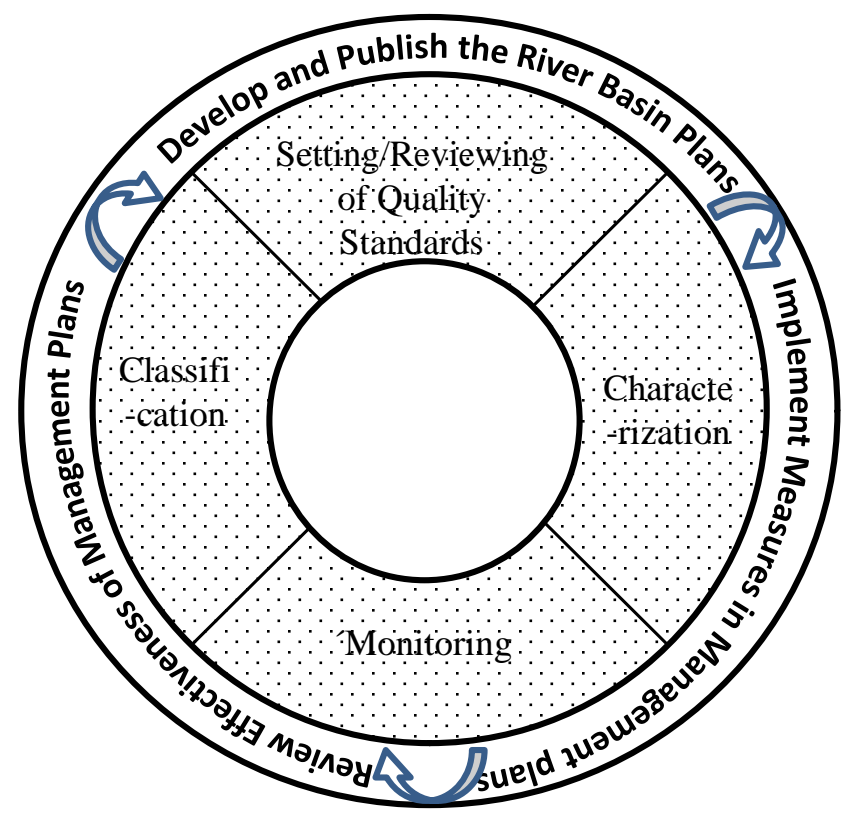

Figure 9. Water Monitoring Procedure adapted under the EU Water Framework Directive (WFD). 


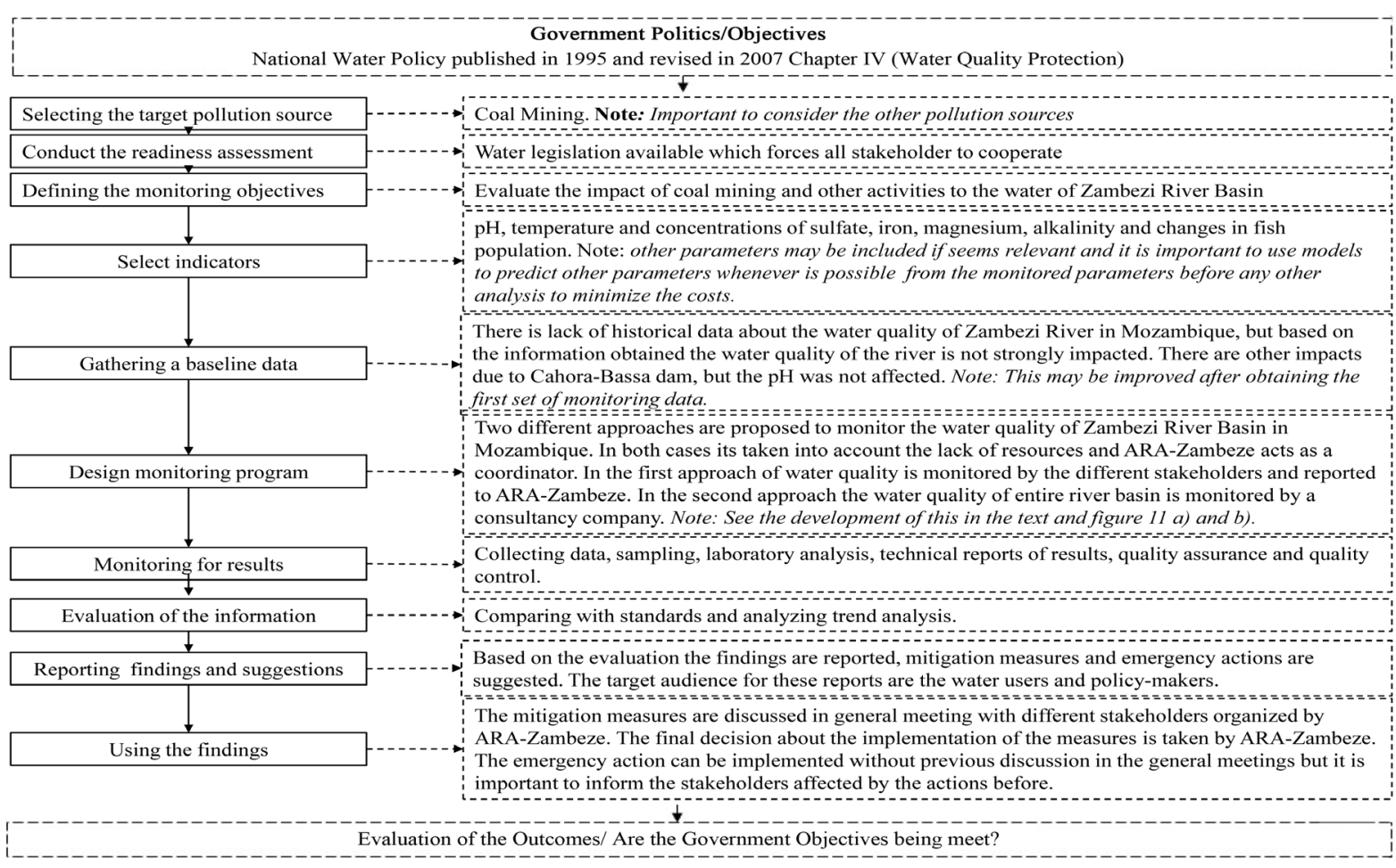

\section{Figure 10. Water monitoring system proposed for the Zambezi River Basin in Mozambique.}

Since coal mining and associated activities are considered to be a major potential threat to the water quality of Zambezi River Basin, it is reasonable to consider coal mining as one of the main target pollution sources for the monitoring system.

The Framework for Water Quality Monitoring (FWQM) suggests that a research question should be raised before defining the monitoring objective. In this case the following question is formulated: To what extent does the coal mining impact the water quality of the Zambezi River Basin and what is the contribution of other sources of pollution? When the question has been defined, the next step is to identify the main constraints to the implementation of the water quality monitoring program, which in this case are lack of resources and weak communication between the stakeholders.

The following step is to define a set of indicators as suggested in the third step of the result-based monitoring and evaluation system (RMES). The most suitable indicator of water being affected by mining is $\mathrm{pH}$, since it indicates the presence of acid mine drainage (AMD).

When there is a risk of AMD, it is also important to consider the content of sulfate, iron, magnesium, and other metal ions, as well as changes in the fish population. These parameters have to be determined in the case of a $\mathrm{pH}$ drop. It is also important to monitor the alkalinity, which helps to predict the capacity of the water to resist $\mathrm{pH}$ changes. Other parameters to be monitored can be identified during the first stage of the monitoring.

In order to make the proposed system work efficiently, it is important to improve the monitoring procedures. The methods used in surveillance monitoring by ARA-Zambeze have to be the same as the ones used for operational monitoring by all other institutions. At present each company is doing operational monitoring according to its own methods, which makes it difficult to ensure comparability of data.

Under these conditions two possible approaches to water quality monitoring procedures are proposed. In both cases ARA-Zambeze should act as a coordinator. In the first approach ARA-Zambeze performs the surveillance monitoring and lets each institution do the operational monitoring as it is now (Figure 11(a)). In this case ARAZambeze has to ensure that each institution uses the appropriate methods in order to guarantee consistency and comparability. In the second approach, probably the most cost effective one, it is proposed to have a consultancy company managing the surveillance monitoring and the operational monitoring for the whole river basin. In this case each institution has to pay a fee for the monitoring (Figure 11(b)), and ARA-Zambeze must convince all other institutions to accept to have the same consulting company doing the monitoring. 


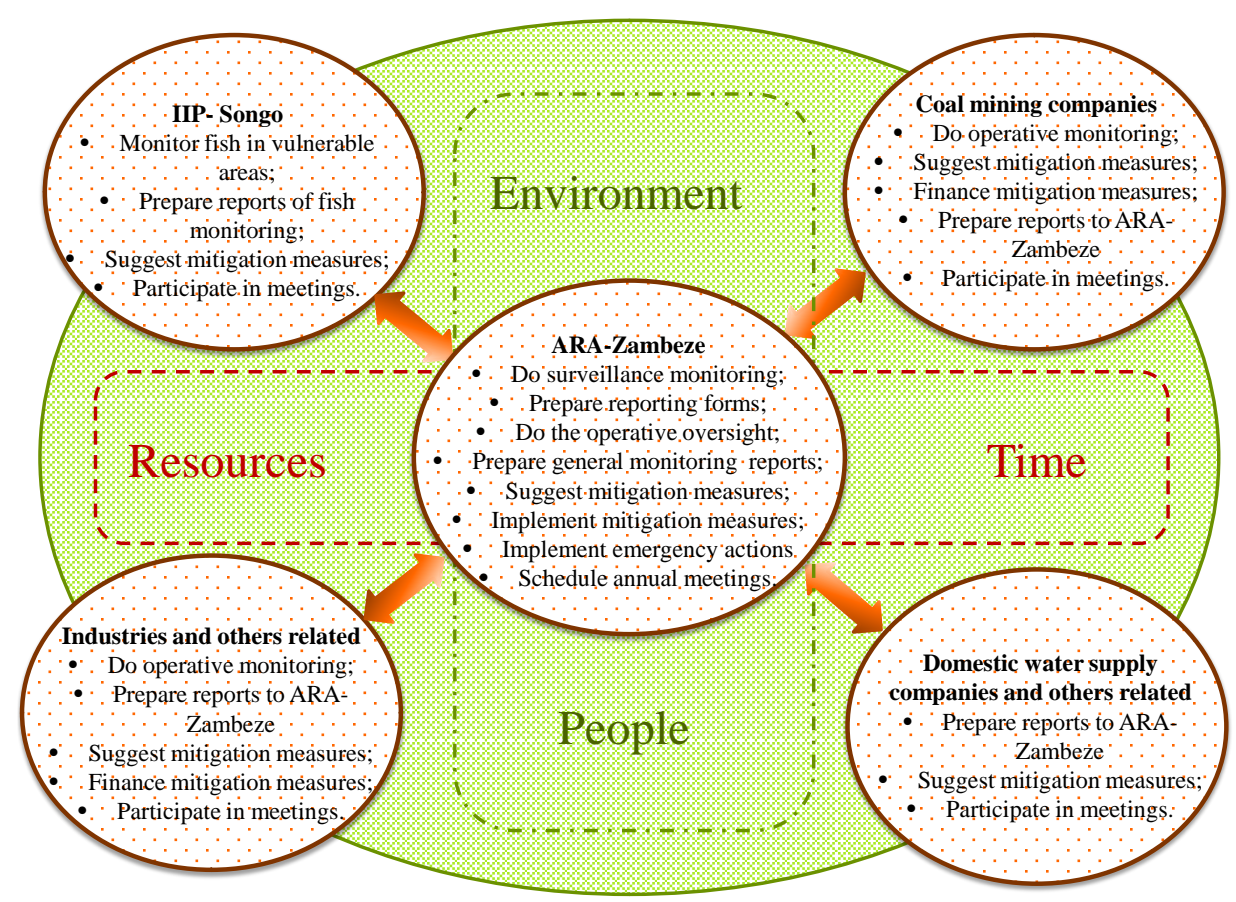

(a)

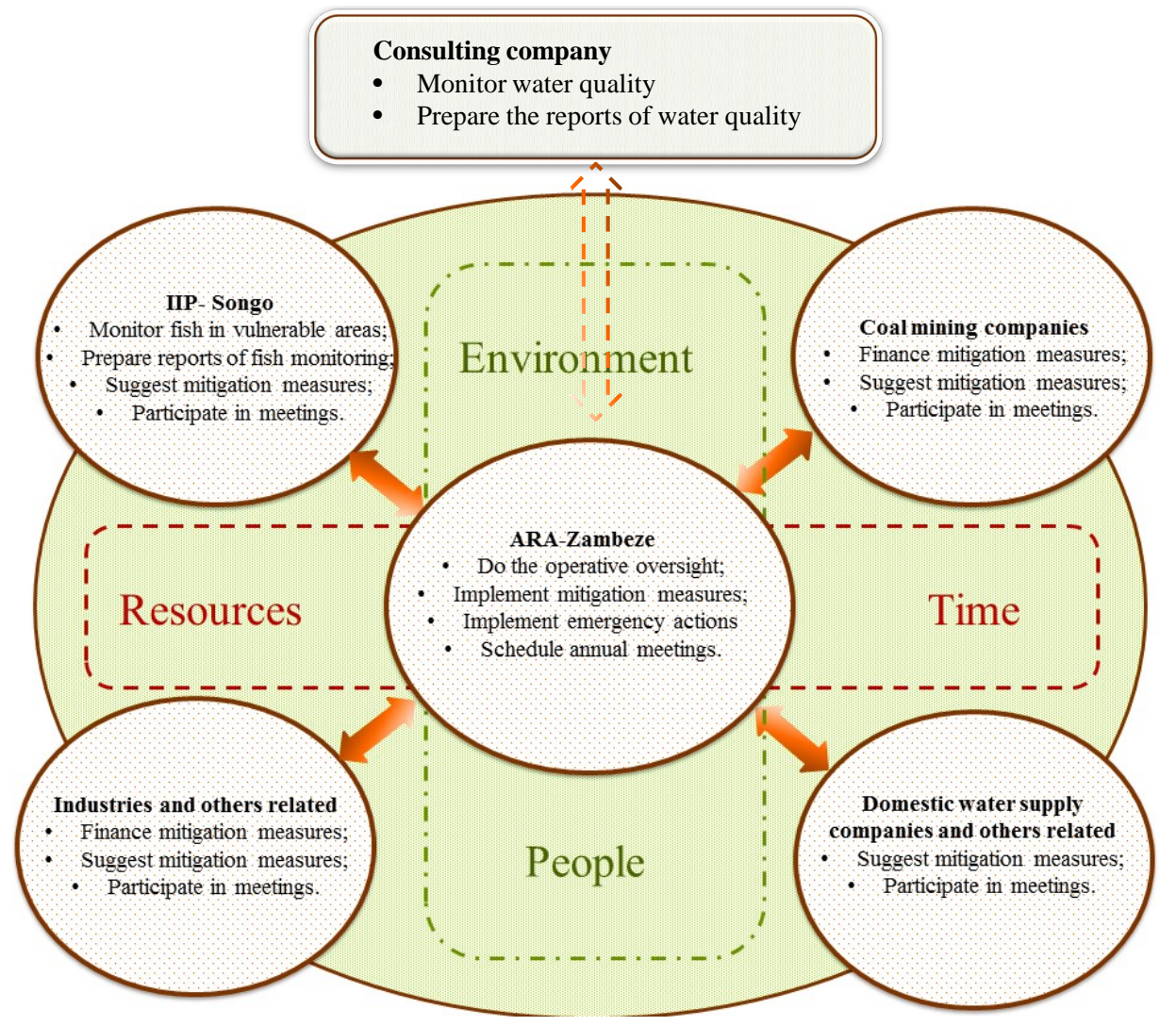

(b)

Figure 11. Water quality monitoring procedure proposed for the Zambezi River Basin in Mozambique. (a) First approach of water quality monitoring procedure; (b) Second approach of water quality monitoring procedure. 
Five important actors are included in the water quality monitoring procedure proposed for the Zambezi River Basin in Mozambique. They are ARA-Zambeze, IIP-Songo, the Coal Mining Companies, Industry and related users, and the Domestic Water Supply Companies and related users. It is also important to consider the affected elements, i.e., the environment and the people; and the limiting factors, resources, and time available, see Figure 11.

ARA-Zambeze should establish the connections between the other actors and should have the responsibility for the following tasks: prepare and update the monitoring system; do the operative oversight; prepare the general water quality reports; decide about the emergency actions and mitigation measures of the water quality changes; make all other stakeholders participate in the monitoring; and prepare meetings to discuss the water quality changes whenever necessary. Before mitigation measures are implemented, they have to be analyzed in the general water quality meetings, where all stakeholders can give their opinion. The emergency actions can be implemented by ARA-Zambeze without being analyzed in the general meetings, but all stakeholders who will be affected by the actions have to be informed in advance.

The responsibilities of each actor in the water quality monitoring procedures proposed are indicted in Figure 11. In the first approach, ARA-Zambeze and all other actors except IIP-Songo have responsibilities that are shifted to a consulting company in the second approach (Figures 11(a)-(b)). The IIP-Songo will also play an important role by doing the fish monitoring and report to ARA-Zambeze.

The second approach of the monitoring is more efficient than the first one, but it requires a suitable agreement with all stakeholders. This fact makes it recommendable to start by implementing the first approach and then move to the second approach.

Samples of surface water and groundwater should be taken in the upstream and downstream areas of each coal mine. The optimal sampling frequency will be estimated and then applied after a preliminary monitoring period, since it depends on the risk of contamination and available resources.

The monitoring system was designed to fulfill the immediate objectives of monitoring, which are to check to which extent the water quality of the Zambezi River Basin is affected by the coal mining and the contribution of other sources of the pollution. It is even more important to check to if the requirements of the government in terms of water quality protection are being met. This includes doing the monitoring, as well as selecting and implementing mitigation measures necessary to protect the water resources.

The monitoring of water quality coordinated by ARA-Zambeze should meet the expectations of all stakeholders within Mozambique, but it also has to consider the monitoring done in other countries which are coordinated by ZAMCOM. This makes it important to consider the general objectives of monitoring defined by ZAMCOM and the activities in other countries that may influence the water quality of the river.

The coal mining in Tete is going on already and the impacts may come soon, during the operations and/or after the operations have ceased. It is therefore necessary to make a detailed analysis of the resources available in relation to the time available to take action before any severe impact may occur. To ensure sustainability and low cost of the monitoring system, data should be managed using web-based software through which all stakeholders have access to input data and can download reports for internal use.

Further research would help to improve the water quality monitoring system proposed for the Zambezi River Basin in Mozambique. It is also necessary to investigate the risk of acid mine drainage generation in Tete. Furthermore, a detailed readiness assessment of the stakeholders to the implementation of a water quality monitoring system should be conducted. It would be most useful if a model could be developed to predict other water quality parameters based on $\mathrm{pH}$ and the response of the river to a drop in $\mathrm{pH}$.

\section{Discussion and Recommendations}

The Zambezi River Basin is the largest river basin in Southern Africa with a total area of $1370.000 \mathrm{~km}^{2}$ and a mean flow of $4100 \mathrm{~m}^{3} / \mathrm{s}$ at the outlet. It sustains life in the eight riparian countries, which include Angola, Botswana, Malawi, Mozambique, Namibia, Tanzania, Zambia, and Zimbabwe. There are many activities taking place in the river basin, such as fishing and agriculture, and there is also a high potential to generate hydropower. The mouth of the Zambezi River and about $11 \%$ of the total catchment area are located in Mozambique, which makes the country vulnerable to activities taking place in the upstream countries.

The coal mining is developing fast in Mozambique due to its favourable geological conditions. The three most important coal deposits of Mozambique are located in the Zambezi River Basin. The National Directorate of Mining in Mozambique has made coal production projections until 2028. It is expected that the coal production 
rises from 2.9 millions of tons in 2011 to 39.0 millions of tons in 2019 , and after this peak the production will drop down to 6.7 millions of tons in 2028.

The coal production may cause significant impact on the water quality of the Zambezi River Basin. This makes it important to establish a water quality monitoring program that takes into consideration the actual development of coal mining, as well as other activities that may impact the water quality of the Zambezi River Basin, such as agriculture, aquaculture, livestock, and the generation of domestic and industrial wastewater.

ARA-Zambeze is a river basin organization that is responsible for the water quality monitoring in the Zambezi River Basin in Mozambique. This institution is currently facing problems due to lack of resources. Actually, ARA-Zambeze is doing limited surveillance monitoring while the institutions using and/or affecting the water quality are doing the operational monitoring and some research institutions are doing investigative monitoring. There is only limited communication between ARA-Zambeze and the other institutions dealing with water quality monitoring, which makes the information produced less accessible to ARA-Zambeze.

Considering the present situation, as well as the projected increase in coal mining, there is a need to develop a water quality monitoring system that takes into consideration the lack of resources in ARA-Zambeze, and that enhances the communication between ARA-Zambeze and other institutions doing water quality monitoring within the river basin.

Two different approaches are suitable for water quality monitoring for Zambezi River Basin in Mozambique. One approach lets each institution do the monitoring in its area of influence (as it is now) and report to ARAZambeze. The other approach would involve a consulting company doing the water quality monitoring. The second approach seems to be more efficient since it would generate more consistent and comparable data. However, it would probably be a challenge to convince all companies to have the same consulting company doing the water quality monitoring. It is suggested that the process should start by applying the first water quality monitoring approach and slowly move to the second system.

In order to move towards a more sustainable monitoring system, it is important to allocate resources for research and development. Some topics of strategic importance are: 1) assessment of the readiness of different stakeholders to the implementation of a water quality monitoring system; 2) development of a model to predict several water quality parameters based on indicator parameters such as $\mathrm{pH}$ and alkalinity; and 3) development of a model to predict the response of the river and aquifers to $\mathrm{pH}$ changes. These models may be used to derive additional parameters from other more basic parameters and to predict water quality changes over time, thus reducing the number of parameters monitored and the sampling frequency. In this way costs for analyses and sampling can be lowered considerably, thereby reducing the overall cost of the monitoring.

The monitoring system developed for ARA-Zambeze should not only focus on the immediate objective of checking to what extent the water quality is being impacted by the coal mining and other activities taking place in the river basin. It should also fulfill the objectives of the government, which is to ensure that the water resources are protected, in order to get the necessary financial support.

Finally, all activities of monitoring in Mozambique have to be developed considering the regional objectives defined by ZAMCOM that takes into consideration the international interests, agreements, and influences.

\section{Conclusion}

In the Zambezi River Basin where different activities, including coal mining, affect the water quality, it is essential to establish a sustainable water quality monitoring system. Due to the limited resources, it is important to enhance the data-sharing between the governmental institution responsible for water quality monitoring (ARAZambeze) with the water users and polluters (including the coal mining companies) to maximize the understanding of water quality changes based on water quality data presently generated by insolated monitoring done by these institutions. The next step forward from data-sharing should be to centralize the water quality monitoring by having only one institution doing the monitoring in the whole river basin. By following such a strategy, it is possible to minimize the overall cost of water quality monitoring and increase the consistency and comparability of data. As a cost-effective supplement to sampling and analyzing water, models should be used to estimate the parameters which are expensive to determine, and to make predictions of future water quality changes.

\section{References}

[1] Besharati, N.A. (2012) Raising Mozambique: Developing Through Coal. Governance of Africa’s Resources Programme. 
[2] World Bank (2009) Bacia do Rio Zambeze-Análise de Oportunidades de Investimento Multissectorial. Banco Mundial,Gestão de Recursos Hídricos, Região de África, Washigton DC.

[3] KPMG (2013) Mozambique-Mining Country Guide. KPMG, Maputo.

[4] Nascimento, F.M.F., Mendonça, R.M.G., Macêdo, M.I.F. and Soares, P.S.M. (2014) Impactos Ambientais nos Recursos Hídricos da Exploraão do Carvão em Santa Catarina. Servico Geológico do Brasil, Santa Catarina.

[5] WWF (2011) Coal and Water Futures in South Africa: A Case for Conserve Headwaters in the Enkangala Grassland. World Wide Fund, Cape Town.

[6] USGS (2012) USGS Education. http://education.usgs.gov/lessons/africa/act1_arcgis.html

[7] SADC-WD/Zambezi River Authority (2007) Rapid Assessment Final Report-Integrated Water Resources Managment Strategy for the Zambezi River Basin. Euro Conultant Mott MacDonalds, Lusaka.

[8] Hipólito, J.R. and Vaz, A.C. (2011) Hidrologia e Recursos Hídricos. Editora Universitaria do Instituto Superior Tecnico, Lisboa.

[9] ARA-Zambeze (2014) Administração Regional de Águas do Zambeze, 2014. http://www.arazambeze.gov.mz/

[10] ARA-Zambeze (2012) Balanço Anual de Actividades. ARA-Zambeze, Tete.

[11] Vale Moçambique Lda (2010) Estudo de Impacto Ambiental do Complexo Industrial de Moatize em Expansão; Volume-II Caracterização da Situação de Referência. Vale Moçambique, Maputo.

[12] Bills, R. (1999) An Inventory of Fishes from the Lower Zambezi River, Mozambique. JLB Smith Institute of Ichthyology, Grahamstown.

[13] Kirchhoff, C. and Bulkley, J. (2008) Sustainable Water Management in the Zambezi River Basin. Journal of International Institute, 15, 10.

[14] MacDonald, M. (2012) Mott MacDonald. http://www.environment.mottmac.com/projects/?mode=type\&id=149669

[15] ZAMCOM (2005) Zambezi Watercourse Commission. http://www.zambezicommission.org/about.php

[16] Alexandre, E. (2012) Potencial para a Produção Adicional de Carvão na Região Norte de Moçambique. Ministerio dos Recursos Minerais-Direcção Nacional de Minas, Maputo.

[17] RM (2012) Radio Moçambique. http://www.rm.co.mz/index.php?option=com content\&view=article\&id=2610:tete-quatro-novas-multinacionais-inicia m-exploracao-do-carvao\&catid=3:breves \&Itemid=370

[18] Vasconselhos, L. (2009) PUCRIS-Pontifícia Universidade Católia do Rio Grande do Sul. http://www.pucrs.br/cepac/download/3SGC/Lopo_Vasconcelos_Coal_in_Mozambique.pdf

[19] Dharmappa, H.B., Sivakumar, M. and Singh, R.N. (2002) Wastewater Characteristics, Management and Reuse in Mining Processing Industries. In: Vigneswaran, S., Ed., Wastewater Recycle, Reuse and Reclamation, EBook, 337-371. http://www.eolss.net/sample-chapters/c07/e2-14-02-06.pdf

[20] ELAW (2010) Overview of Mining and Its Impacts. In: Guidebook for Evaluating Mining Project, Environmental Law Alliance Worldwide, Eugene, 8-9.

[21] Office of Water, Engineering and Analysis Division (2000) Coal Mining Best Management Practices Guidance. US Environmental Protection Agency, Washington DC.

[22] Inter-Ministerial Committee (2010) Mine Water Management in the Witwatersrand Gold Fields with Special Emphasis on Acid Mine Drainage. Inter-Ministerial Committee, South Africa.

[23] Jennings, R.S., Neuma, D.R. and Blicker, P.S. (2008) Acid Mine Drainage and Effects on Fish Health and Ecology: A Review. Reclamation Reseach Group Publication, Bozeman, MT.

[24] WMO (2013) Planning of Water-Quality Monitoring Systems. World Meteorological Organization, Geneva.

[25] Kusek, J.Z. and Rist, R.C. (2004) Ten Steps to a Results-Based Monitoring and Evaluation System. World Bank, Washington DC. http://dx.doi.org/10.1596/0-8213-5823-5

[26] AWRA (2004) Seeking a Common Framework for Water Quality Monitoring. American Water Resources Association, New York.

[27] Peter, C.A. and Ward, R.C. (2004) A Framework for “Constructing” Water Quality Monitoring Programs. Water Resources IMPACT (American Water Resources Association), 5, 3-7.

[28] Spooner, C.S. and Mallard, G.E. (2004) Identify Monitoring Objectives. Water Resources IMPACT (American Water Resources Association), 5, 11-13.

[29] Oslen, A.R. and Robertson, D.M. (2004) Monitoring Design. Water Resources IMPACT (American Water Resources Association), 5, 14-16.

[30] Wild, F., Brass, H.J. and Diamond, J. (2004) Data Collection: Field and Laboratory Methods. Water Resources IMPACT 
(American Water Resources Association), 5, 17-21.

[31] Klima, K.S., Lanfear, K.F. and McCarron, E. (2004) Water Quality Data Management. Water Resources IMPACT (American Water Resources Association), 5, 22-24.

[32] Helsel, D.L. and Griffith, L.M. (2004) Assess and Interpret Data. Water Resources IMPACT (American Water Resources Association), 5, 25-29.

[33] Ambrose, M., Arkowitz, A.M. and Job, C. (2004) Conveying Results and Findings. Water Resources IMPACT (American Water Resources Association), 5, 30-32.

[34] IWRM Plan Joint Venture Namibia (2010) Integrated Water Resources Management Plan for Namibia. Ministry of Agriculture, Water and Forest, Windhoek.

[35] EPA (2014) Environmental Protection Agency. http://www.epa.ie/water/watmg/wfd/\#.VBB25_mSyhs

[36] EPA (2006) Water Framework Directive Monitoring Programme. Environmental Protection Agency, Wexford. 